\title{
Review \\ Microfluidic-Chip-Integrated Biosensors for Lung Disease Models
}

\author{
Shuang Ding ${ }^{1,+}$, Haijun Zhang ${ }^{1, *,+} \mathbb{C}$ and Xuemei Wang ${ }^{2, *}$ \\ 1 Department of Oncology, Zhongda Hospital, School of Medicine, Southeast University, \\ Nanjing 210009, China; dingshuang@seu.edu.cn \\ 2 State Key Laboratory of Bioelectronics, School of Biomedical Engineering, Southeast University, \\ Nanjing 210096, China \\ * Correspondence: haijunzhang@seu.edu.cn (H.Z.); xuewang@seu.edu.cn (X.W.); Tel.: +86-25-83-792-177 (X.W.) \\ + These authors contributed equally to this work.
}

check for

updates

Citation: Ding, S.; Zhang, H.; Wang,

X. Microfluidic-Chip-Integrated

Biosensors for Lung Disease Models. Biosensors 2021, 11, 456. https:// doi.org/10.3390/bios11110456

Received: 10 October 2021

Accepted: 14 November 2021

Published: 15 November 2021

Publisher's Note: MDPI stays neutral with regard to jurisdictional claims in published maps and institutional affiliations.

Copyright: () 2021 by the authors. Licensee MDPI, Basel, Switzerland. This article is an open access article distributed under the terms and conditions of the Creative Commons Attribution (CC BY) license (https:// creativecommons.org/licenses/by/ $4.0 /)$.

\begin{abstract}
Lung diseases (e.g., infection, asthma, cancer, and pulmonary fibrosis) represent serious threats to human health all over the world. Conventional two-dimensional (2D) cell models and animal models cannot mimic the human-specific properties of the lungs. In the past decade, human organ-on-a-chip (OOC) platforms-including lung-on-a-chip (LOC)-have emerged rapidly, with the ability to reproduce the in vivo features of organs or tissues based on their three-dimensional (3D) structures. Furthermore, the integration of biosensors in the chip allows researchers to monitor various parameters related to disease development and drug efficacy. In this review, we illustrate the biosensor-based LOC modeling, further discussing the future challenges as well as perspectives in integrating biosensors in OOC platforms.
\end{abstract}

Keywords: biosensor; microfluidics; organ-on-a-chip; lung model; lung-on-a-chip

\section{Introduction}

\subsection{Lung Physiology and Diseases}

The lungs are among the most important organs in the human body, and are a site for gas exchange. They contain many alveoli with a large total surface area and abundant capillaries wrapped around them. Both alveolar walls and capillary walls are composed of a layer of epithelial cells, which are conducive to gas exchange between the alveoli and the blood. The respiratory membrane is the vital structure for gas exchange, and can be divided into six layers: a liquid layer containing alveolar surfactant, the alveolar epithelial layer, the epithelial basement membrane layer, an interstitial layer between the alveoli and capillaries, the capillary basement membrane layer, and the capillary endothelial cell layer [1]. Common respiratory diseases include inflammation (pneumonia) [2], chronic obstructive pulmonary disease (COPD) [3,4], asthma [5], lung cancer [6-8], pulmonary fibrosis, pulmonary embolism, etc. They occur in different anatomical regions (e.g., alveoli or small airways), with varied pathogenesis and therapeutic principles.

\subsection{Microfluidic Chips}

In the 1990s, in order to meet the need for more sensitive, efficient, and rapid separation and analysis of biological samples, Manz and Widmer et al. [9] first proposed the concept of miniaturized total analysis systems ( $\mu$ TASs). Today, such systems have developed into one of the most advanced scientific and technological fields in the world. The core technology is based on microfluidic chip systems, or lab-on-a-chip systems [10]. This refers to the integration of sample preparation, reaction, separation, detection, and other basic operational units involved in conventional chemical and biological fields into a chip of several square centimeters, which has the advantages of rapid detection and analysis, large amounts of information, and high throughput. In recent decades, such systems have been 
widely used in life sciences, disease diagnosis, and drug screening, becoming among the most popular frontier technologies in the 21st century.

\subsection{Lung Models}

At present, in vitro two-dimensional (2D) cell models/three-dimensional (3D) spheroids, animal models, and human organoid models are commonly used to mimic the lungs, but these models all have their limitations. Monolayer cell culture is simple and cheap, but cannot demonstrate the complex structure and function of the human-organ-specific microenvironment in vivo. 3D spheroids based on hydrogel scaffolds are more similar to the microenvironment, but still have the disadvantages of no perfusion, no stress, and limited vasculature. Animal models, although widely used, are not able to mimic human-specific features, with poor prediction value for patients due to the great differences in respiratory system structure between animal models and humans. Lung organoids can provide a variety of cell types and more complex tissue-specific functions, but they cannot mimic organ-level features of the lungs, such as tissue-tissue interface, epithelial-endothelial crosstalk, and immune cell-host response. These models cannot analyze the recruitment of circulating immune cells under active fluid flow, causing unavoidable problems in the modeling of lung diseases. Therefore, there is an urgent need to develop alternative preclinical models to better mimic the pathophysiology of human lungs. Microfluidic technology is able to handle small volumes of fluids $\left(10^{-9}\right.$ to $\left.10^{-18} \mathrm{~L}\right)$ across microchannels with dimensions from tens to hundreds of micrometers, which promote the development of human organ-on-a-chip (OOC) systems with the ability to successfully mimic many aspects of the organ-level physiology [11]. A large number of OOC platforms integrated with microfluidic technologies, organ anatomy, physics, materials science, and cell biology have been designed for an array of human organs, including the lungs [12-14], liver [15-17], gut [18,19], kidneys [20,21], and heart [22,23]. Lung-on-a-chip (LOC) [24], as the first proposed OOC, has always been an appealing research topic for mimicking ALI structure or breathing movement, reducing the awkwardness of lung modeling. LOC is a multifunctional microexperimental platform that can reproduce the key structural, functional and mechanical properties of the human alveolar-capillary interface (ACI, the basic functional unit of living lungs), simulate lung function at the organ level, and reflect the tissue-tissue interface, epithelial-endothelial crosstalk, and immune cell-host response. There have been many reports on the application of lung alveolus-on-a-chip and small-airway-on-a-chip systems in simulating lung inflammation, pulmonary edema, pulmonary fibrosis, viral pneumonia, and lung cancer.

\subsection{Biosensors}

Biosensors are a kind of chemical sensor. They are a signal analysis tool composed of immobilized biologically sensitive material components (including enzymes, antibodies, antigens, microorganisms, cells, tissues, nucleic acids, etc.), corresponding transducers (including oxygen electrodes, photosensitive tubes, field-effect tubes, piezoelectric crystals, etc.), and a signal detecting device. Biosensors [25] are used to detect biological analytes (e.g., biomolecules), structures, and microorganisms, and can monitor and transmit information about a life process [26-28]. As shown in Figure 1, a sensing element (for recognition of biomolecules), signal transducer (for signal translation), and detector (for detecting the signal) make up the sensor. Biosensors were first proposed by Clark et al., who clamped an enzyme solution between two layers of dialysis membrane to form a thin liquid layer, and then glued it to a $\mathrm{pH}$ electrode and an oxygen electrode to detect the reaction in the liquid layer. As the lifetime of the enzyme electrode is relatively short, and the purification is also expensive, researchers began to research derivatives of enzyme electrodes-such as animal tissue electrodes, organelle electrodes, and microbial electrodes-which greatly increased the variety of biosensors. According to the sensing principle, the most common integrated sensors can be classified into three groups: electrical [29,30], electrochemical [31-35], and optical [36-38]. Electrical signals are often used to deal with cell growth 
and responses, while optical and electrochemical sensors are commonly used to detect chemical signals. Various integrated biosensors have been used for chemical analysis in microfluidic chips [39]. The basic concept of the reported microfluidic-based biosensor is to integrate the analysis functions required for biochemical analysis on a single chip, including sample preparation, pretreatment, detection, and molecular sorting. The combination of biosensors and microfluidic chips improves analysis capabilities and broadens the range of possible applications. Recently, some efforts have been made to integrate biosensors into OOC platforms as well.

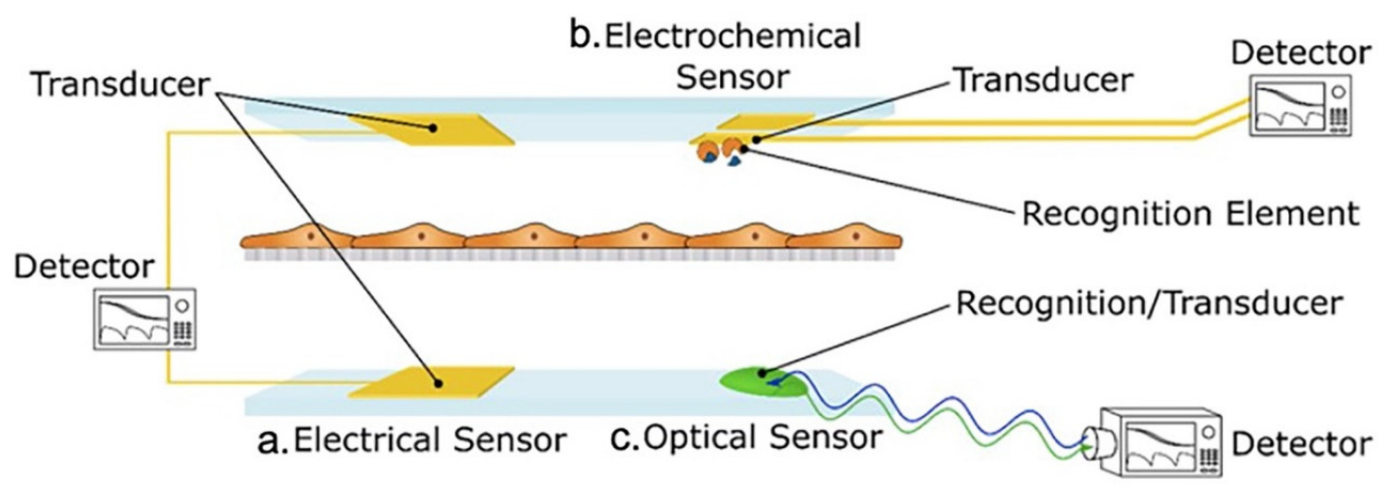

Figure 1. Composition and classification of sensors: Sensors are classified into (a) electrical sensors, (b) electrochemical sensors, and (c) optical sensors. Reproduced with permission from [40].

\section{Biosensor-Free LOC for Lung Modeling}

The classical "alveolar lung-on-a-chip" [12] and "small airway lung-on-a-chip" [41,42] were established by Huh et al. and Benam et al., respectively, from the Wyss Institute for Biologically Inspired Engineering at Harvard University (Figure 2). In 2010, Huh et al. [12] produced one of the first biomimetic microfluidic lung models, in which $10 \mu \mathrm{m}$ of polydimethylsiloxane (PDMS) membrane with ECM was sandwiched between the two PDMS microchannels. ALI was generated for gas exchange with the blood. The upper channel contained epithelial cells while the other channel contained microvascular endothelial cells to mimic the ACI. The membrane between the two channels was forced to deform under a vacuum to pneumatic channels on either side of the membrane. The authors found that ALI culture increased the transbilayer electrical resistance (TER, $>800 \Omega \cdot \mathrm{cm}^{2}$ ) and produced tighter ACI as compared to liquid culture conditions. This study became a pioneer for further studies related to LOCs. Benam et al. [41] introduced a human small airway lung-on-a-chip containing mucociliary bronchiolar epithelium and microvascular endothelium; this chip was made of PDMS containing an upper channel and a parallel lower microvascular channel, which were separated by a polyester membrane coated with type I collagen on both sides. Physiological and pathological processes of the lungs were simulated and developed based on this small airway lung-on-a-chip; the authors also modeled several airway diseases [43,44] (e.g., asthma [45], lung inflammation [42], COPD, and COPD exacerbation [13]) on the chip.

In 2012, Huh et al. mimicked pulmonary edema on a chip [46], the structure of which was similar to the alveolar lung-on-a-chip mentioned above. This pulmonaryedema-on-a-chip reproduced lung function in response to interleukin-2 (IL-2), and also successfully screened a drug for pulmonary edema. Zamprogno et al. [47] presented a second-generation LOC with a lung alveolar array based on a biological, thickness/stiffnesscontrolled membrane made from collagen and elastin via a simple method. Huang et al. [48] used a model of the human alveoli based on physiological structure; it was composed of a 3D porous hydrogel with an inverse opal structure, and then bonded to a PDMS chip. In contrast to traditional PDMS or biological membranes, the inverse opal hydrogel structure is similar to human alveolar sacs, with well-defined, interconnected pores, and can be introduced to LOCs. Zhang et al. $[49,50]$ evaluated the pulmonary toxicity of $\mathrm{TiO}_{2} / \mathrm{ZnO}$ 
nanoparticles and fine particulate matter (PM2.5) exposure using a novel three-channel 3D LOC model. Hassell et al. [14] created a chip model of human non-small-cell lung cancer (NSCLC) to recapitulate cancer growth, responses to tyrosine kinase inhibitor (TKI) therapy, and dormancy. Xu et al. [51] reported a multiorgan chip with an upstream "lung" and three downstream "organs", which mimicked the lung cancer metastasis microenvironment. In general, these LOC models mentioned above were biosensor-free, although with different design concepts and applications (see Table 1 for detailed comparisons). Given the biological complexity of the described LOC, future progress must be made in biosensor integration in order to easily monitor related physiological parameters.

(a)
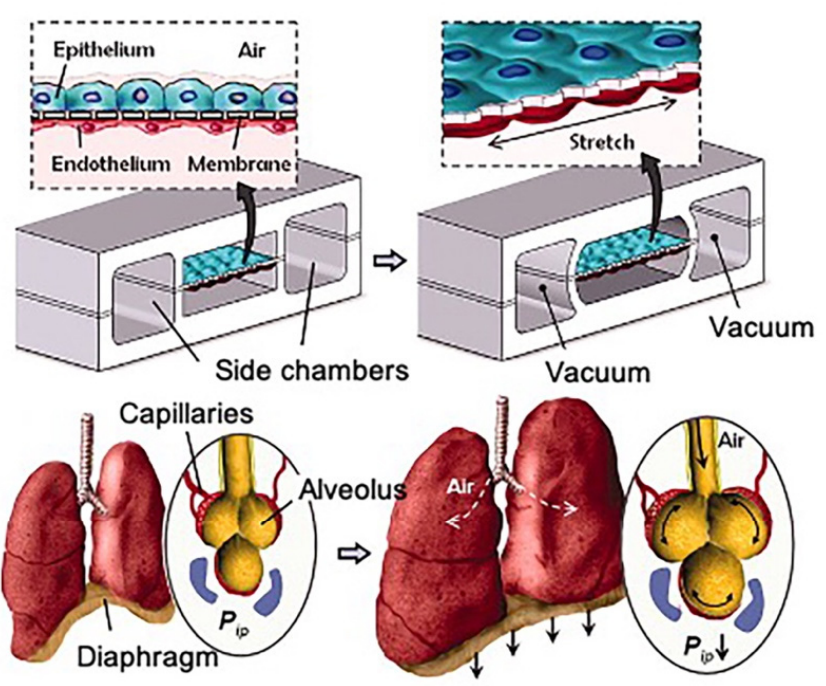

(b)

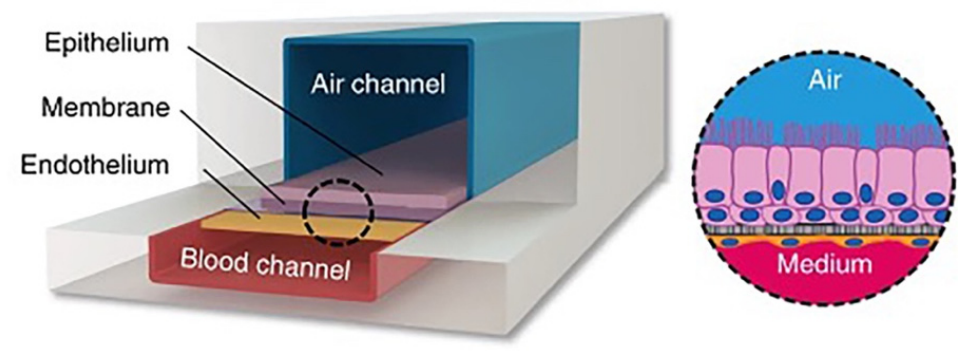

Figure 2. Design of two classical human breathing LOC microdevices: (a) Schematic diagram of "alveolar lung-on-a-chip"; physiological breathing movements were reproduced by applying vacuum to the chambers; reproduced with permission from [12]. (b) Schematic diagram of the "small airway lung-on-a-chip"; reproduced with permission from [42].

Table 1. Literature review of some biosensor-free LOCs. Chip models, structure of ACI, corresponding remarks, and whether respiration movement was observed are listed in the table for comparison.

\begin{tabular}{|c|c|c|c|c|}
\hline Chip Models & Structure of ACI & Remarks & $\mathrm{RM}^{1}$ & Ref. \\
\hline $\begin{array}{c}\text { Alveolar } \\
\text { lung-on-a-chip }\end{array}$ & $\begin{array}{c}\text { Alveolar epithelial } \\
\text { cells/PDMS/microvascular } \\
\text { endothelium }\end{array}$ & $\begin{array}{l}\text { A pioneer for further studies } \\
\text { related to LOC. The authors } \\
\text { also introduced } \\
\text { pulmonary-edema-on-a-chip to } \\
\text { mimic lung function, and } \\
\text { screened a new drug for } \\
\text { pulmonary edema }\end{array}$ & Yes & [12] \\
\hline
\end{tabular}


Table 1. Cont.

\begin{tabular}{|c|c|c|c|c|}
\hline Chip Models & Structure of ACI & Remarks & $\mathbf{R M}^{1}$ & Ref. \\
\hline $\begin{array}{l}\text { Small airway } \\
\text { lung-on-a-chip }\end{array}$ & $\begin{array}{l}\text { Differentiated mucociliary } \\
\text { bronchiolar epithe- } \\
\text { lium/PDMS/microvascular } \\
\text { endothelium }\end{array}$ & $\begin{array}{l}\text { Modeled asthma, lung } \\
\text { inflammation, and COPD } \\
\text { exacerbation on the chip, and } \\
\text { also evaluated the therapeutic } \\
\text { response on the chip }\end{array}$ & $\begin{array}{l}\text { With ALI } \\
\text { structure }\end{array}$ & {$[13,41,42]$} \\
\hline $\begin{array}{l}\text { A chip model of } \\
\text { human NSCLC }\end{array}$ & $\begin{array}{l}\text { Similar to alveolar } \\
\text { lung-on-a-chip }\end{array}$ & $\begin{array}{l}\text { Recapitulated cancer growth, } \\
\text { responses to TKI therapy, } \\
\text { and dormancy }\end{array}$ & Yes & {$[14]$} \\
\hline $\begin{array}{l}\text { Second-generation lung } \\
\text { alveolar array }\end{array}$ & $\begin{array}{c}\text { Human primary alveolar } \\
\text { epithelial cells } \\
\text { (hAEpCs)/collagen-elastin } \\
\text { membrane/human lung } \\
\text { microvascular endothelial cells }\end{array}$ & $\begin{array}{c}\text { Biological, stretchable, } \\
\text { biodegradable, and } \\
\text { thickness/stiffness-controlled } \\
\text { collagen-elastin membrane } \\
\text { outperforms PDMS in } \\
\text { many ways. }\end{array}$ & Yes & {$[47]$} \\
\hline $\begin{array}{l}\text { Physiologically } \\
\text { relevant model of } \\
\text { human alveoli }\end{array}$ & $\begin{array}{l}\text { hAEpCs/alveoli-like 3D GelMA } \\
\text { hydrogels/human umbilical } \\
\text { vein endothelial cells (results } \\
\text { with HUVEC only available in } \\
\text { the Supplementary Materials) }\end{array}$ & $\begin{array}{l}\text { 3D porous hydrogel with an } \\
\text { inverse opal structure bonded to } \\
\text { a compartmentalized PDMS } \\
\text { chip. Investigated the } \\
\text { pathological effects of cigarette } \\
\text { smoking and } \\
\text { SARS-CoV-2 infection }\end{array}$ & Yes & {$[48]$} \\
\hline $\begin{array}{l}\text { Three-channel } \\
\text { 3D LOC model }\end{array}$ & $\begin{array}{c}\text { Alveolar epithelial } \\
\text { cells /ECM/pulmonary vascular } \\
\text { endothelial cells }\end{array}$ & $\begin{array}{l}\text { Evaluated the pulmonary } \\
\text { toxicity of } \mathrm{TiO}_{2} / \mathrm{ZnO} \\
\text { nanoparticles and } \\
\text { PM2.5 exposure }\end{array}$ & No & {$[49,50]$} \\
\hline $\begin{array}{l}\text { Multiorgan lung cancer } \\
\text { metastasis-on-a-chip }\end{array}$ & $\begin{array}{l}\text { Human bronchial epithelial and } \\
\text { lung cancer } \\
\text { cells / PDMS/microvascular } \\
\text { endothelial cells, fibroblasts, } \\
\text { and macrophages }\end{array}$ & $\begin{array}{l}\text { Upstream "lung" and } \\
\text { downstream "brain", "bone", } \\
\text { and "liver" to mimic the in vivo } \\
\text { microenvironment of } \\
\text { cancer metastasis }\end{array}$ & Yes & {$[51]$} \\
\hline
\end{tabular}

${ }^{1} \mathrm{RM}$ refers to respiration movement.

\section{Biosensors in Microfluidic Chips for Lung Modeling}

Biosensors have been widely used in the field of analysis, as they can carry out online and continuous monitoring in complex systems, with the properties of high automation, miniaturization, and integration. When biosensors are combined with new approaches, they can have a revolutionary impact on biotechnology. In the following section, we mainly introduce microfluidic chips for lung modeling, along with integrated biosensors for detecting related parameters. Although some microfluidic chips do not have the structure of LOCs, they have successfully achieved the sensing of specific parameters, laying a foundation for the integration of biosensors in LOCs.

\subsection{Transepithelial Electric Resistance (TEER)}

Traditional techniques for the measurement of TEER are not suitable for microfluidic devices that replicate the dynamic microenvironment of lung respiration movements [52]. It is difficult to place the microelectrodes on the chip such that the biomimetic capability of the chip is protected and cells are easily accessed via simple handling.

In 2017, Henry et al. [53] from the Wyss Institute described a newly developed human airway-on-a-chip with embedded electrodes for TEER biosensors (Figure 3). Four electrodes were integrated into a microfluidic device that they developed previously [42]. The chip was fabricated using polycarbonate (PC) as a base substrate for its high optical clarity, cell culture biocompatibility, ease of machining, compatibility with metal deposition processes, and ease of chemical surface modification. Epoxy moieties were introduced at the PDMS 
surface using GLYMO prior to the binding of plasma-activated PDMS to the silanol groups introduced at the PC surface via aminopropyltriethoxysilane (APTES) treatment. This method improved bonding efficacy and enabled long-term resistance to hydrolytic cleavage. Electrodes were $1 \mathrm{~mm}$ wide, spaced $1 \mathrm{~mm}$ apart, and patterned on PC substrates using a laser-patterned, silicon-coated, backing paper shadow mask. These electrodes were not only stable, but also transparent, allowing for real-time monitoring using optical microscopy. The authors successfully maintained the chip for 62 days in culture and 56 days at ALI, without any evidence of cell toxicity from the presence of the gold and titanium layers. This biosensor can be used in OOC modelling of barriers (e.g., the blood-brain barrier), as it enables measurement of barrier function in cultured cells.

(a)

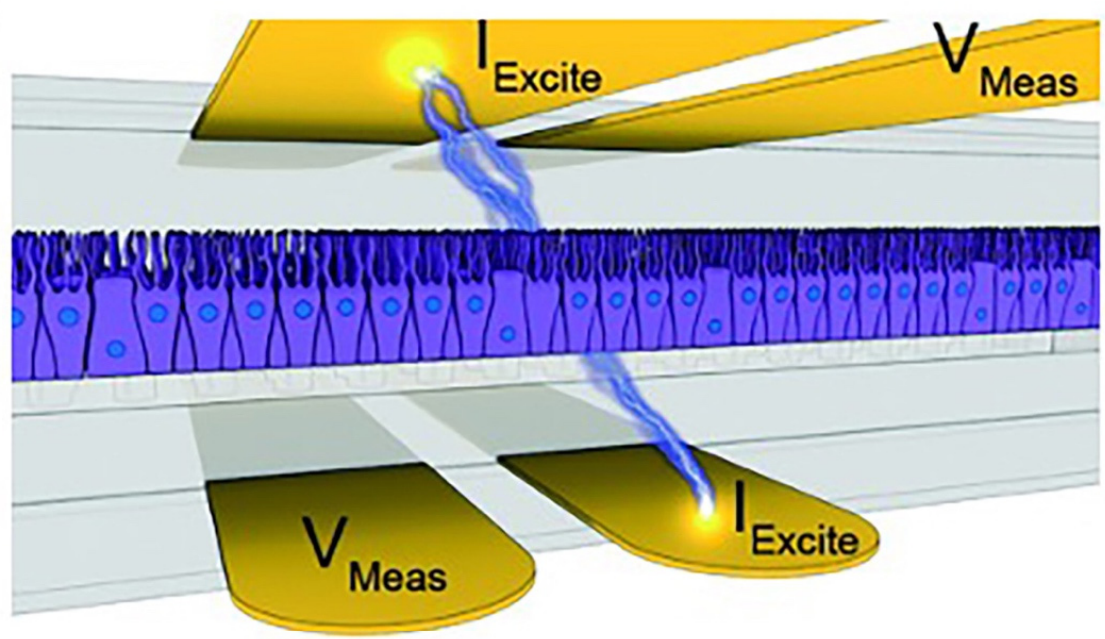

(b)

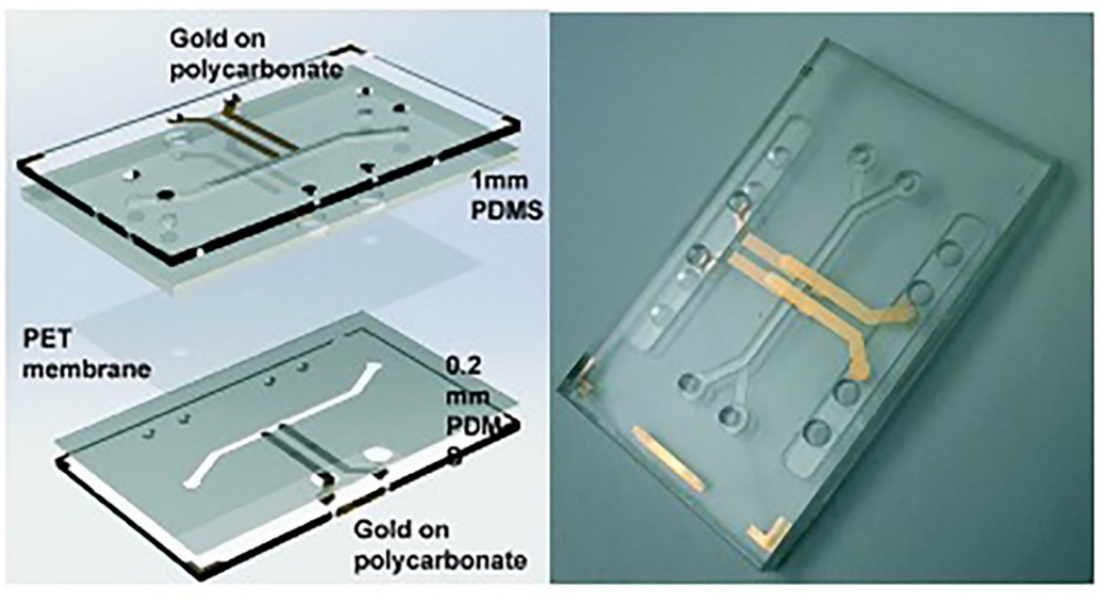

Figure 3. Microengineered human airway-on-a-chip with TEER biosensor: (a) Schematic view of the TEER chip's working principle. (b) Photograph of the assembled TEER chip. Reproduced with permission from [53].

Increased information output can be obtained by using different types of biosensors in one chip. Khalid et al. [54] introduced a lung-cancer-on-a-chip system equipped with multiple sensors (Figure 4). The chip was prepared in-house by inkjet printing the elastomeric microfluidic channel onto the glass. The top and bottom glasses were held together by a 3D-printed chip holder. During the $54 \mathrm{~h}$ real-time monitoring, different concentrations of chemotherapeutics were introduced to NCI-H1437 cells; meanwhile, real-time data of media $\mathrm{pH}$ and TEER impedance were obtained via optical $\mathrm{pH}$ sensor and top/bottom ITO electrodes. Optical sensors for non-invasive $\mathrm{pH}$ monitoring of media were assembled using commercial electronics, white LEDs, optical filters, photodiodes, and $3 \mathrm{D}$ printing. The working principle is that when the $\mathrm{pH}$ of the extracellular culture medium changes, the color of phenolic red in the culture medium flowing through trans- 
parent and biocompatible microfluidic channels changes, and the change in $\mathrm{pH}$ can be quantified by measuring the change in light intensity in the channels. Optical $\mathrm{pH}$ sensors were characterized and calibrated in the $\mathrm{pH}$ range 6.0-8.5 using standard $\mathrm{pH}$ media samples. The culture media $\mathrm{pH}$ and impedance were monitored for 2 days without any problems in a typical experiment. Then, $500 \mathrm{~nm}$ transparent indium tin oxide (ITO)-based TEER impedance-sensing electrodes were patterned using the photolithography technique. The active area of the electrodes was $16 \mathrm{~mm}^{2}$. The TEER impedance data converted to the cell index (CI) (normalized impedance values) showed that an increase in the drug concentrations caused higher cell death rates. The authors concluded that increased drug concentration caused medium acidification and higher cell death rates due to an increase in the number of acidic molecules; furthermore, these sensors could also be used in drug screening systems, and the chip introduced by the authors was also a promising tool for the development of personalized medicine.

(a)
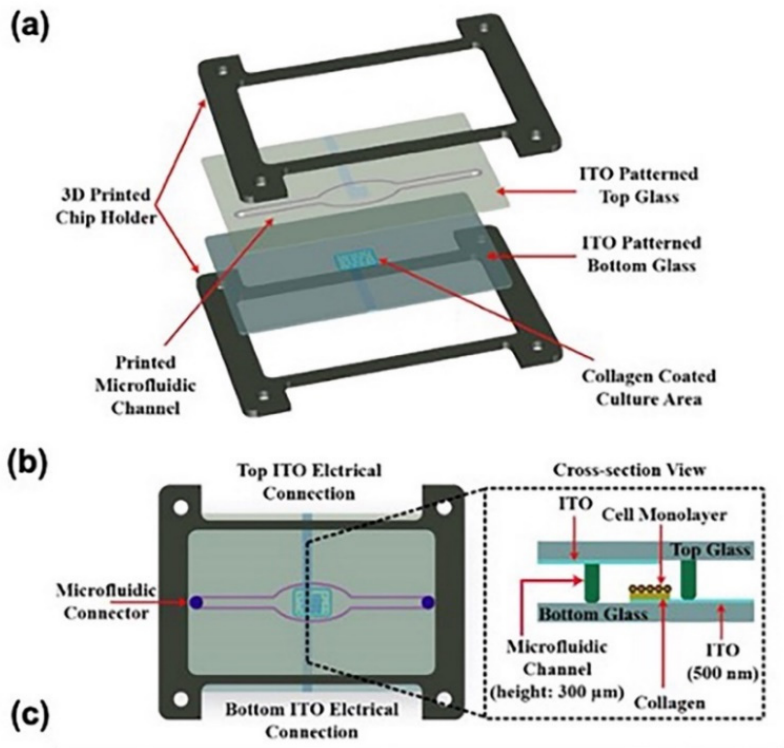

(c) Connection

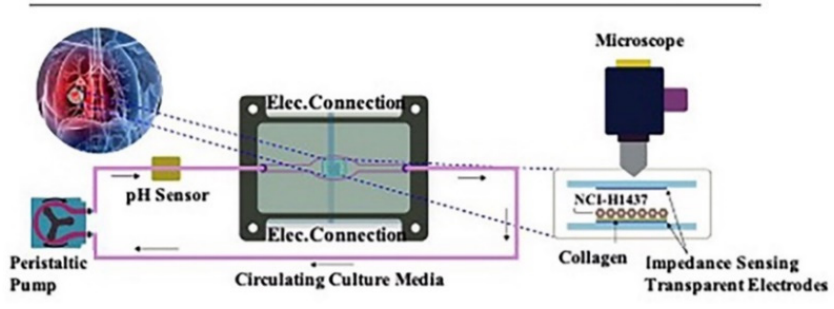

Figure 4. Lung-cancer-on-chip system with multiple sensors: (a) Cross-section view and (b) top view of microfluidic glass chip fabrication. (c) Working flow of the chip for physiological environment monitoring and drug cytotoxicity evaluation. Reproduced with permission from [54].

Mermoud et al. [55] reported a new micro-impedance tomography (MITO) system with the ability to monitor changes in the lung alveolar barrier at a distance of $1 \mathrm{~mm}$ from the electrodes using impedimetric coplanar electrodes (Figure 5). They integrated the system into an LOC that models breathing movement through a thin film, based on their previous study [56]. The sensing system was produced using a printed circuit board (PCB). The electrodes on the PCB consisted of $35 \mu \mathrm{m}$ of copper covered with an electroless nickel plating and a $50 \mathrm{~nm}$ thick layer of immersion gold. The flexible PCB was irreversibly bonded with oxygen plasma between the actuation membrane and the actuation part, providing the LOC with barrier function monitoring in a simple, cost-effective manner. 
(a)
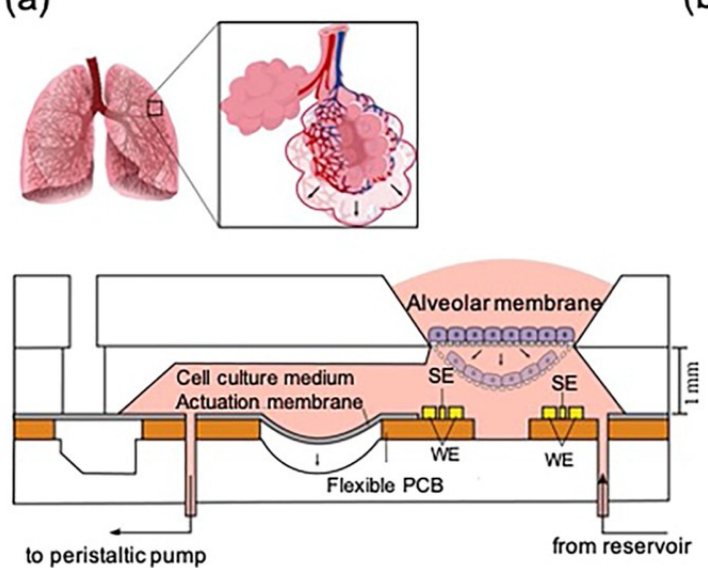

(b)

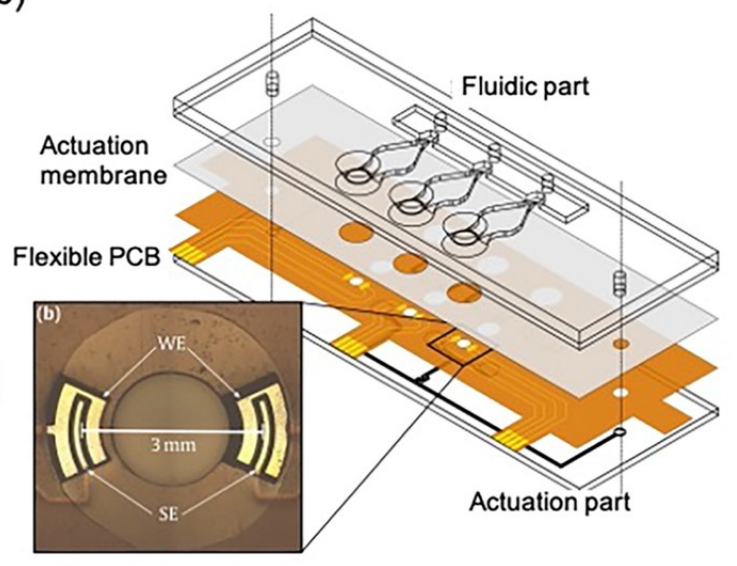

Figure 5. LOC integrated with a MITO system: (a) Cross-sectional view of the system. (b) Detailed information about the flexible PCB that can be bonded between two layers in the LOC. Reproduced with permission from [55].

The single-organ LOC can mimic lung cell culture microenvironments, but cannot reproduce the interactions between the lungs and other organs. Combining multiple organ types within a single chip can better model the in vivo microenvironment, and is urgently needed. Skardal et al. [57] described a three-tissue OOC system (liver, heart, and lungs; see Figure 6). Liver and cardiac organoids were integrated into a circulatory perfusion system, which was connected to a lung module with an ALI. Lung modules were composed of endothelial cells, lung fibroblasts, and epithelial cells over a semi-permeable membrane within the chip. Transepithelial resistance (TEER) and short-circuit current (Isc) electrophysiological sensing functions were realized by advanced electrodes. The surfaces of the electrodes were functionalized by immobilizing streptavidin (SPV) on the working electrode via covalent bonding with EDC/NHS. The system was maintained for more than 9 days, with direct monitoring of organoid integrity and organ function. The authors found that bleomycin - a drug that causes lung fibrosis and inflammation-also caused toxicity in the cardiac organoids by releasing inflammatory cytokines, including IL-1 $\beta$. The advanced in vitro drug screening capability of the system represents an important contribution to the field of drug development.

As the most commonly used type of biosensors in OOCs, electrical sensors measure voltage to determine cell properties and physical properties. Optical sensing relies on various forms of microscopy, without consumption of the analyte. Electrochemical sensors work by catalyzing an analyte into another active product. With the application of sensors in biology, more and more biosensors are used to detect biochemical indicators, and not simply to detect some physical parameters. In the following section, we mainly classify the different sensing targets—such as respiratory viruses, biomarkers (e.g., deoxyribonucleic acid (DNA), ribonucleic acid (RNA), proteins, cells), drug efficacy, oxygen, temperature, etc.-in biosensor-based microfluidic chips for lung modeling.

\subsection{Respiratory Virus Infections}

Since 2019, COVID-19 has been a global pandemic. The current gold standard for diagnosis is viral nucleic acid testing, which is time consuming and labor intensive. Therefore, there is an urgent need for a fast and accurate virus detection method. Qiu et al. [58] reported a dual-functional plasmonic biosensor combining the plasmonic photothermal (PPT) effect and localized surface plasmon resonance (LSPR) to sense transduction for the clinical diagnosis of COVID-19. On the one hand, complementary DNA-receptor-functionalized two-dimensional gold nano-islands (AuNIs) can achieve sensitive detection of the selected sequences from severe acute respiratory syndrome coronavirus 2 (SARS-CoV-2) via nucleic acid hybridization. On the other hand, the AuNIs can enhance the sensing performance by generating thermoplasmonic heat. Jin et al. [59] developed a useful system for the detection 
of human respiratory adenovirus (HAdV) by combining a biosensor with a microfluidic sample processing module. The detection of viral DNA was accomplished by using a biooptical sensor of isothermal solid-phase DNA amplification after the DNA was extracted from clinical samples within 30 min using a disposable thin film to facilitate the viral DNA extraction from clinical samples.

a
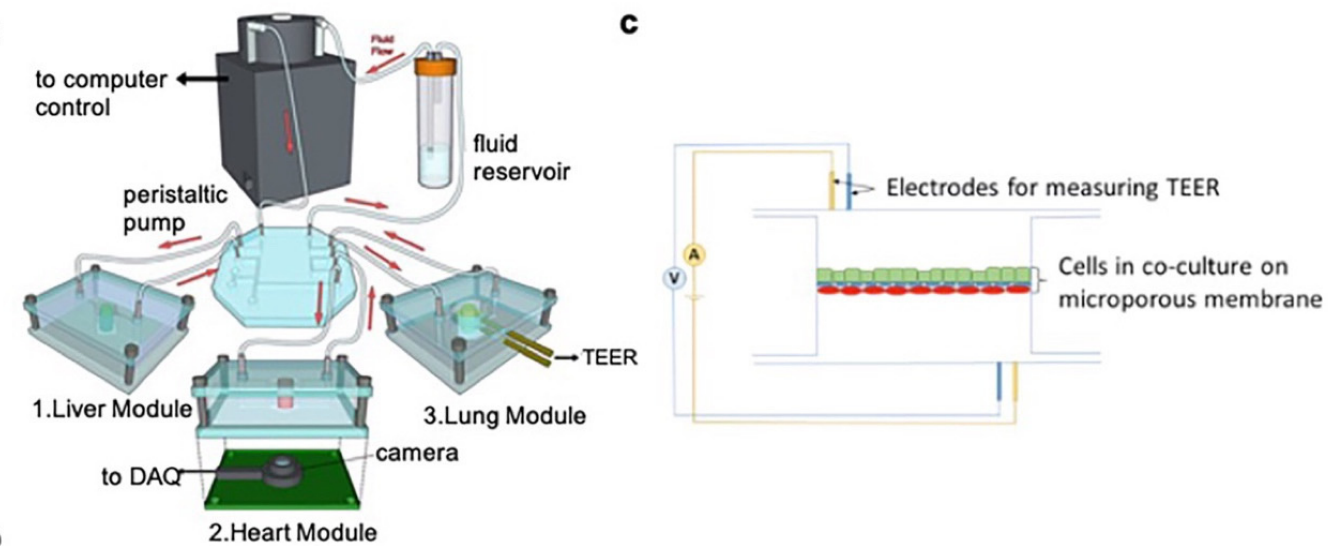

b

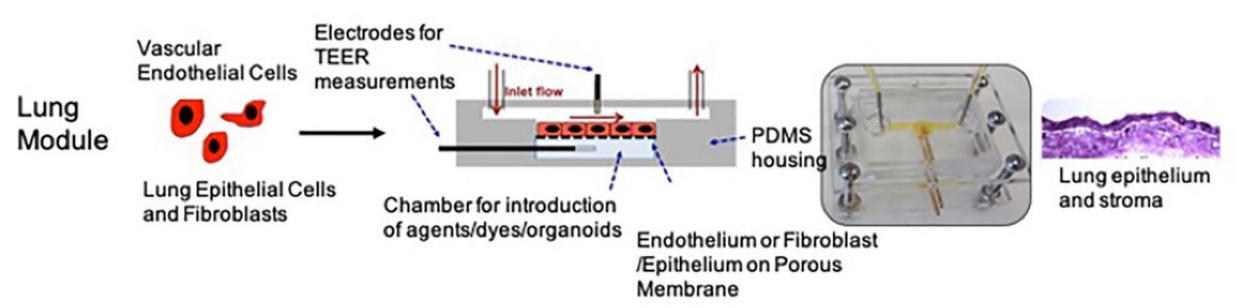

Figure 6. Overall design of the 3-tissue OOC system: (a) Illustration of the system. (b) Lung modules are formed within microfluidic devices. (c) TEER sensors in lung modules are introduced to monitor tissue barrier function over time. Reproduced with permission from [57].

\subsection{Lung Cancer Biomarkers}

Biomarkers refer to biomolecules that are signs of normal or abnormal processes, conditions, or diseases found in bodily fluids or tissues. They can be used to monitor the progression and efficacy of a disease-especially in cancer [60-65].Biomarkers include DNA, RNA, and proteins (e.g., antigens, cytokines). They are widely detected in bodily fluids such as blood, urine, saliva, tears, and cerebrospinal fluid. Combined detection of multiple tumor markers can improve the sensitivity and specificity of tumor diagnosis. In the following section, biosensors for lung cancer at the molecular level (DNA, RNA, and proteins), organelle level (exosomes), and cell level (circulating tumor cells (CTCs)) are comprehensively discussed.

\subsubsection{Molecular Level (DNA, RNA, and Proteins)}

DNA [66,67], RNA [68,69], and proteins play important roles in early-stage cancer diagnosis, but their detection remains a challenge because of low expression levels [70-72]. Traditionally, cancer-related circulating tumor DNA (ctDNA) is usually detected via personalized analysis of rearranged ends (PARE), whole-genome sequencing, or digital PCRbased methods. MicroRNAs (miRNAs) [73], as a class of small, non-coding endogenous RNAs of $\sim 22$ nucleotides long, are traditionally detected by real-time qPCR, Northern blotting, microarray, and deep transcriptome sequencing (RNA-Seq). Lung cancer protein biomarkers [74-76] — such as antigens (NSE, SCC, etc.), MMPs, and cytokines—are widely used in clinical practice. Extensive efforts have been devoted to developing ultrasensitive biosensors for the detection of cancer protein biomarkers.

Sheng et al. [77] introduced a dual signal amplification strategy, which was integrated on an electrochemical biosensor for the rapid detection of RNAs (miRNA-17, miRNA-155, miRNA-19b, miRNA-210, thyroid transcription factor-1 messenger RNA (TTF-1 mRNA) 
and epidermal growth factor receptor (EGFR) mRNA). This platform could selectively and sensitively distinguish early-stage NSCLC patients from healthy controls and benign lung disease patients by identifying low-expression RNA targets in human sera. Portela et al. [78] employed simple colloidal lithography to build a $\mathrm{cm}^{2}$-sized nanostructured plasmonic biosensor chip based on nanogap antennas. miRNA-210, a biomarker of lung cancer, was detected by this chip via a DNA/miRNA hybridization assay. The sensing potential was proven to be excellent, owing to a limit of detection (LOD) of $0.78 \mathrm{nM}$. Aoki et al. [79] fabricated a 384-channel biosensor array chip for the detection of multiple mRNAs and miRNAs for lung cancer. The individual biosensor was composed of a photolithographically fabricated $\mathrm{Au} / \mathrm{Cr}$-based electrode modified with peptide nucleic acid (PNA) probes. Sequence-specific responses were proven on the chip with an LOD of $73.3 \mathrm{nM}$. Furthermore, potential use with polymerase chain reaction (PCR) samples was suggested by PCR-amplified oligonucleotide samples. Zeng et al. [80] developed a novel anchor-like DNA (alDNA) electrochemical biosensor for the detection of Kirsten rat sarcoma viral oncogene (KRAS) point mutation level. Compared to the conventional ligation-based DNA biosensors, the alDNA biosensor was convenient and cheap, with high sensitivity and selectivity; it could capture both wild-type and mutant DNA in one step. Furthermore, mutation detection in blood samples could meet the requirements for early-stage NSCLC diagnosis in clinical settings. Wu et al. [81] developed a chip consisting of gold-coated cover glass and tethered cationic lipoplex nanoparticles (tCLN) containing molecular beacons (MBs), which could capture cancer-cell-derived exosomes or viruses and identify encapsulated RNAs in a single step. The CLNs were able to fuse with the exosomes and form nanoparticle complexes via electrostatic interaction. Then, the MBs hybridized with the target RNAs, and exosomes enriched in the target RNAs were detected by the fluorescence signals of MBs using total internal reflection fluorescence (TIRF) microscopy. Furthermore, only $60 \mu \mathrm{L}$ of serum and $2.5 \mathrm{~h}$ were needed in this system, which showed very promising prospects in the detection of exo-miRNAs and clinical diagnosis.

Chiu et al. [82] constructed a signal amplification sensing film for the detection of the cytokeratin 19 fragment (CYFRA21-1). This novel surface plasmon resonance (SPR) detection assay was ultrasensitive, with an LOD of $0.05 \mathrm{pg} / \mathrm{mL}$ in spiked clinical sera, which is $10^{4}$ times more sensitive than an enzyme-linked immunosorbent assay (ELISA). Cheng et al. [83] developed field-effect transistor (FET) biosensors to detect CYFRA21-1 and neuron-specific enolase (NSE) in both serum and phosphate-buffered saline (PBS); they also integrated two antibody types on the same chip for simultaneous multiplexed detection. Zou et al. [84] introduced a chip cartridge packaged with a Love wave biosensor for the measurement of CEA, NSE, and squamous-cell carcinoma (SCC) antigen in exhaled breath condensate $(\mathrm{EBC})$ collected from both healthy volunteers and lung cancer patients; gold nanoparticles were immobilized onto the biosensor by a sandwich immunoassay. In addition to tumor markers, specific antigens involved in different processes of disease can also help in the diagnosis and prognosis of disease, such as epithelial-mesenchymal transition (EMT) transcription factor, and inflammatory indicators such as C-reactive protein (CRP) and procalcitonin (PCT). Chakravarty et al. [85] demonstrated a silicon chip platform integrated with photonic crystal (PC) microcavity biosensors to detect the EMT transcription factor zinc finger E-box-binding homeobox 1 (ZEB1) in lysates from NCI-H358 cells. The shift in resonance wavelength resulting from the changed refractive index in the PC microcavity could detect the binding of the corresponding antigen. Feng et al. [86] integrated a microelectrode and a cathodic photoelectrochemical (PEC) biosensor into a microfluidic chip for the detection of CYFRA21-1, based on a signal amplification strategy with a detection limit of $0.026 \mathrm{pg} / \mathrm{mL}$.

In addition to the detection of individual biomarkers, multivariate detection has also been widely practiced. Washburn et al. [87] described the simultaneous detection of eight cancer biomarkers (alpha fetoprotein (AFP), activated leukocyte cell adhesion molecule (ALCAM), cancer antigen 15-3 (CA15-3), cancer antigen 19-9 (CA19-9), cancer antigen 125 (CA-125), carcinoembryonic antigen (CEA), osteopontin, and prostate-specific antigen 
(PSA)) in serum using an antibody-based sandwich assay, in $1 \mathrm{~h}$, based on silicon photonic biosensors. Gao et al. [88] designed a giant magnetoresistance (GMR) multi-biomarker immunoassay biosensor that could simultaneously detect 12 kinds of tumor marker (AFP, CEA, CYFRA21-1, NSE, SCC, PG I, PG II, CA19-9, total PSA, free PSA, free-beta-hCG, and $\mathrm{Tg}$ ) to screen patients with lung cancer, liver cancer, digestive tract cancer, prostate cancer, etc. The GMR sensor chip was based on a double-antibody sandwich immunoassay method. Gao et al. [89] developed a label-free assay for the multiplexed detection of lung cancer biomarkers (miRNA-126 and CEA) using silicon nanowire field-effect transistor (SiNW-FET) sensors. Integration of the SiNW sensor and PDMS microfluidic device enables rapid, sensitive, and multiplexed detection.

\subsubsection{Organelle Level (Exosomes)}

Cancer-derived exosomes [90-92] with a size of 30-150 $\mathrm{nm}$ and density of 1.13-1.19 g/mL have drawn much attention in recent decades, and can be obtained from bodily fluids (such as serum, plasma, or urine). They carry a variety of information on the tumor and tumor microenvironment; thus, they play important roles in tumorigenesis and progression. The detection of such biomarkers is useful for the early diagnosis and drug sensitivity analysis of cancer. Yang et al. [93] presented a novel microfluidic device for the isolation and in situ detection of lung-cancer-specific exosomes collected from patients' urine. The integrated biosensor was fabricated using poly(methyl methacrylate) (PMMA) and a nonporous gold $\mathrm{Au}$ ) nanocluster membrane modified with the capture antibody. The change in scattering intensity due to resonance Rayleigh scattering enables the ultrasensitive detection of exosomes.

\subsubsection{Cell Level (Circulating Tumor Cells (CTCs))}

CTCs are the tumor cells that are separated from the primary solid tumor and enter the bloodstream for various reasons. They play an important role in early diagnosis, detection of tumor recurrence and metastasis, prognostic evaluation, and treatment guidance. The detection and characterization of CTCs provide a non-invasive approach for monitoring cancer therapy. Chen et al. [94] designed a magnet-deformability hybrid integrated microfluidic chip to enumerate CTCs. NSCLC patient blood samples were used to validate the microfluidic chip clinically, with a high capture efficiency (over $90 \%$ at $3 \mathrm{~mL} / \mathrm{h}$ ) and high viability (96\%) at high flow rates. Nguyen et al. [95] combined dielectrophoretic (DEP) manipulation and impedance measurement using a single microfluidic device equipped with circular microelectrodes to detect CTCs; the force of DEP and hydrodynamic drag drove A549 lung cancer cells to the center of the working region; the LOD of the impedance biosensor was approximately three cells. The same group [96] also introduced a microdevice with electrical sensors based on aptamer-modified gold electrodes for the detection of A549 cells. This device permitted not only optical microscope observations, but also electrical impedance spectroscopy (EIS) measurements. Nabovati et al. [97] introduced an array of charge-based capacitive measurement biosensors for high-throughput cell growth monitoring; the authors tested both $\mathrm{H} 1299$ cells and polystyrene beads, with consistent results with cell-based assays; the results showed that the capacitive electrodes can successfully detect cell attachment and growth. Do et al. [98] combined a DEP microfluidic enrichment platform with a capacitive biosensor to detect CTCs; A549 cells were driven to the working chamber via DEP forces, and then captured by an anti-EGFR modified electrode; finally, cells were detected according to their different capacitance. Li et al. [99] developed a cell isolation microfluidic device based on electrotactic ability; this chip was composed of three parts: a cell immobilization structure, an electric field (EF) generator, and a cell retrieval module. The results show that H1975 cell motility was related to EGFR expression and upregulation of ras homolog family member A (RhoA), regardless of EF stimulation, while it was also related to phosphatase and tensin homolog deleted on chromosome ten (PTEN) expression in the presence of EF stimulation. 


\subsection{Drug Efficacy}

Drug efficacy evaluation is important in clinical treatment and drug development. Traditionally, the measurement of cell responses to drugs requires cell counting kit-8 (CCK8), methyl thiazolyl tetrazolium (MTT) assays, animal models, etc., but the biosensor-equipped chip simplifies this process. The corresponding result can be read directly through the biosensor. Pan et al. [100] developed a microgroove impedance sensor (MGIS) for monitoring 3D A549 cell viability in a dynamic and non-invasive manner. Cells were planted in microgrooves for in situ impedance measurement. The proliferation and apoptosis of cells indicated by the change in the living cell number caused an inversely proportional change in the impedance magnitude. The results based on this MGIS platform were very similar to the clinically observed effects of chemotherapy on NSCLC. Noh et al. [101] reported in-air monitoring of in vitro monolayer cells by EIS; two chambers in the chip were separated by a porous membrane, on which EIS electrodes were patterned and A549 cells were cultured. Unlike conventional TEER, electrodes were placed laterally-instead of vertically-to the membrane. This in-air EIS biosensor can enable not only the monitoring of cell population, but also the modulation of tight junctions.

\subsection{Oxygen and Temperature}

Oxygen and temperature are two of the most important physical parameters in the process of cell culture. Although important, they are the most easily ignored parameters, because of the difficulty in simply reading out these indicators in the traditional culture process. Zirath et al. [102] developed two microfluidic devices integrated with oxygensensitive, microparticle-based biosensor spots. The microdevice was composed of two glass substrates, onto which sensor microparticles were pipetted directly; an adhesive film containing the fluidic structure bonded the two layers together. Partial oxygen pressures, cellular oxygen consumption rates with varying cell types, flow rates, and cell numbers were monitored.

Temperature changes in cells are closely connected with physiological processes. Temperature measurements are beneficial to the study of cellular mechanisms. Zhao et al. [103] developed a microfluidic chip for cellular temperature monitoring using a platinum (Pt) thermosensor. The chip was positioned in a constant water tank $24 \mathrm{~h}$ after cell seeding. The results showed that temperature response to cisplatin differed in different cells. In conclusion, this chip could be applied to study cell physiology and pathology, with the ability to monitor cellular temperature.

In general, microfluidic chips integrated with biosensors for lung disease modeling, with different design concepts and applications, are briefly summarized in Table 2.

Table 2. Literature review of some biosensor-based microfluidic chips for lung disease modeling. Detailed sensing parameters and characteristics of corresponding sensing technology are listed for summary.

\begin{tabular}{cccc}
\hline Sensing Parameter & Sample & Keywords & Advantages \\
\hline Respiratory virus & SARS-CoV-2 & $\begin{array}{c}\text { A dual-functional plasmonic } \\
\text { biosensor combining the } \\
\text { plasmonic photothermal (PPT) } \\
\text { effect and localized surface } \\
\text { plasmon resonance (LSPR) for } \\
\text { sensing transduction }\end{array}$ & $\begin{array}{c}\text { High sensitivity; lower } \\
\text { detection limit; } \\
\text { cost-effective }\end{array}$ \\
\hline HAdV & $\begin{array}{c}\text { Bio-optical sensor of } \\
\text { isothermal solid-phase DNA } \\
\text { amplification; a disposable } \\
\text { thin film to facilitate the } \\
\text { extraction of viral DNA }\end{array}$ & $\begin{array}{c}\text { Low-cost; simplicity; } \\
\text { fast (30 min); simple } \\
\text { instruments }\end{array}$ \\
\hline
\end{tabular}


Table 2. Cont.

\begin{tabular}{|c|c|c|c|c|}
\hline Sensing Parameter & Sample & Keywords & Advantages & Ref. \\
\hline \multirow[t]{5}{*}{ DNA/RNA biomarkers } & $\begin{array}{l}\text { miR-17, miR-155, } \\
\text { TTF1mRNA, miR-19b, } \\
\text { miR-210 }\end{array}$ & $\begin{array}{l}\text { CRISPR/CHDC system; early } \\
\text { cancer diagnosis }\end{array}$ & $\begin{array}{c}\text { High sensitivity; } \\
\text { low-cost; easy } \\
\text { scalability; short assay } \\
\text { time }\end{array}$ & [77] \\
\hline & miR-210 & $\begin{array}{l}\text { Large-area nano-plasmonic } \\
\text { biosensor; nanogap antennas; } \\
\text { customized colloidal } \\
\text { lithography process }\end{array}$ & $\begin{array}{l}\text { Simple; low-cost; direct } \\
\text { and label-free detection; } \\
\text { high sensitivity }\end{array}$ & [78] \\
\hline & $\begin{array}{l}\text { IGFBP5, EGR3, TFF1 } \\
\text { mRNAs, miR-17, } \\
\text { miR-21, miR-223 }\end{array}$ & $\begin{array}{c}\text { 384-Channel, } \\
\text { photolithographically } \\
\text { fabricated electrode; } \\
\text { Au/Cr-based; PNA } \\
\text { probes modified }\end{array}$ & $\begin{array}{l}\text { Simple; low cost; } \\
\text { simultaneous detection }\end{array}$ & [79] \\
\hline & KRAS point mutation & $\begin{array}{l}\text { alDNA electrochemical } \\
\text { biosensor }\end{array}$ & $\begin{array}{c}\text { High accuracy; } \\
\text { convenient, low-cost, } \\
\text { and time-saving, with } \\
\text { broad dynamic range, } \\
\text { and high sensitivity } \\
\text { and selectivity }\end{array}$ & [80] \\
\hline & $\begin{array}{l}\text { miR-21 and TTF-1 } \\
\text { mRNA }\end{array}$ & $\begin{array}{c}\text { Tethered cationic lipoplex } \\
\text { nanoparticles (tCLN) } \\
\text { containing molecular } \\
\text { beacons (MBs) }\end{array}$ & $\begin{array}{l}\text { Non-invasive and } \\
\text { highly } \\
\text { sensitive }\end{array}$ & [81] \\
\hline \multirow[t]{7}{*}{ Protein biomarkers } & CYFRA21-1 & $\begin{array}{l}\text { Carboxyl-functionalized } \\
\text { molybdenum disulfide } \\
\text { (carboxyl-MoS2) } \\
\text { nanocomposites; signal } \\
\text { amplification sensing film }\end{array}$ & High specificity & [82] \\
\hline & CYFRA21-1, NSE & FET biosensor & $\begin{array}{l}\text { Simple and rapid; low } \\
\text { sample consumption; } \\
\text { cheap }\end{array}$ & [83] \\
\hline & CEA, NSE and SCC & $\begin{array}{l}\text { Tumor markers; clinical EBC } \\
\text { samples; gold nanoparticle } \\
\text { sandwich immunoassay }\end{array}$ & $\begin{array}{l}\text { Sensitive, specific, and } \\
\text { rapid; low cost of time } \\
\text { and money; low } \\
\text { sample volume }\end{array}$ & [84] \\
\hline & $\begin{array}{l}\text { ZEB1 in lysates from } \\
\text { NCI-H358 cells }\end{array}$ & $\begin{array}{l}\text { Photonic crystal (PC) } \\
\text { microcavity biosensors }\end{array}$ & $\begin{array}{l}\text { Duplicate or triplicate } \\
\text { analyses; high } \\
\text { sensitivity and } \\
\text { specificity }\end{array}$ & [85] \\
\hline & CYFRA21-1 & $\begin{array}{l}\text { A microelectrode and a } \\
\text { cathodic photoelectrochemical } \\
\text { (PEC) biosensor based on a } \\
\text { signal amplification strategy }\end{array}$ & $\begin{array}{l}\text { Rapid detection; high } \\
\text { selectivity; } \\
\text { cost-effectiveness }\end{array}$ & [86] \\
\hline & $\begin{array}{l}\text { AFP, ALCAM, CA15-3, } \\
\text { CA19-9, CA-125, CEA, } \\
\text { Osteopontin, PSA }\end{array}$ & $\begin{array}{c}\text { Eight cancer biomarkers in } \\
\text { serum; antibody-based } \\
\text { sandwich assay }\end{array}$ & $\begin{array}{l}\text { Rapid }(1 \mathrm{~h}) \text { and } \\
\text { fully automated }\end{array}$ & [87] \\
\hline & $\begin{array}{l}\text { AFP, CEA, CYFRA21-1, } \\
\text { NSE, SCC, PG I, PG II, } \\
\text { CA19-9, total PSA, free } \\
\text { PSA, free-beta-hCG, Tg }\end{array}$ & $\begin{array}{l}\text { A giant magnetoresistance } \\
\text { (GMR) multi-biomarker } \\
\text { immunoassay biosensor; } \\
\text { simultaneously detects } 12 \\
\text { kinds of tumor markers }\end{array}$ & $\begin{array}{l}\text { High throughput; } \\
\text { excellent sensitivity, } \\
\text { accuracy, precision, and } \\
\text { stability; convenient }\end{array}$ & [88] \\
\hline
\end{tabular}


Table 2. Cont.

\begin{tabular}{|c|c|c|c|c|}
\hline Sensing Parameter & Sample & Keywords & Advantages & Ref. \\
\hline & miRNA-126 and CEA & $\begin{array}{l}\text { Silicon nanowire field-effect } \\
\text { transistor (SiNW-FET) }\end{array}$ & $\begin{array}{l}\text { Multiplexed real-time } \\
\text { monitoring; high } \\
\text { sensitivity and } \\
\text { selectivity; label-free; } \\
\text { low-cost }\end{array}$ & [89] \\
\hline Exosomes & $\begin{array}{l}\text { Lung-cancer-specific } \\
\text { exosomes }\end{array}$ & $\begin{array}{l}\text { Isolation and in situ detection; } \\
\text { collected from patients' urine; } \\
\text { nanoporous gold (Au) } \\
\text { nanocluster membrane } \\
\text { modified with the capture } \\
\text { antibody }\end{array}$ & $\begin{array}{l}\text { Fast and ultrasensitive; } \\
\text { simultaneous isolation } \\
\text { and detection }\end{array}$ & [93] \\
\hline \multirow[t]{6}{*}{ CTCs/rare cells } & $\begin{array}{l}\text { CTCs from NSCLC } \\
\text { patient blood }\end{array}$ & $\begin{array}{l}\text { A magnet-deformability } \\
\text { hybrid integrated microfluidic } \\
\text { chip, validated clinically with } \\
\text { a high capture efficiency }\end{array}$ & $\begin{array}{c}\text { Versatile and } \\
\text { high-efficiency; } \\
\text { size/deformability } \\
\text { hybrid }\end{array}$ & [94] \\
\hline & A549 & $\begin{array}{l}\text { DEP manipulation; impedance } \\
\text { measurement; circular } \\
\text { microelectrodes }\end{array}$ & $\begin{array}{c}\text { Simple; rapid; } \\
\text { label-free; low-cost }\end{array}$ & [95] \\
\hline & A549 & $\begin{array}{c}\text { Amine-terminated } \\
\text { aptamer-modified gold } \\
\text { electrodes; early-stage } \\
\text { lung cancer }\end{array}$ & $\begin{array}{l}\text { Simple; cheap; } \\
\text { biocompatible }\end{array}$ & [96] \\
\hline & H1299 cells & $\begin{array}{l}\text { An array of charge-based } \\
\text { capacitive measurement } \\
\text { biosensors for } \\
\text { high-throughput cell growth } \\
\text { monitoring }\end{array}$ & $\begin{array}{l}\text { Label-free and } \\
\text { real-time detection; } \\
\text { high throughput; high } \\
\text { sensitivity }\end{array}$ & [97] \\
\hline & A549 & $\begin{array}{l}\text { Guided and captured; } \\
\text { electrode immobilized by } \\
\text { anti-EGFR }\end{array}$ & High sensitivity & [98] \\
\hline & H1975 cell & $\begin{array}{l}\text { Composed of cell } \\
\text { immobilization structure, } \\
\text { electric field (EF) generator, } \\
\text { and cell retrieval module }\end{array}$ & $\begin{array}{l}\text { Easy cell manipulation } \\
\text { and precise } \\
\text { field control }\end{array}$ & [99] \\
\hline \multirow[t]{2}{*}{ Drug efficacy } & A549 & $\begin{array}{c}\text { MGIS; dynamic and } \\
\text { noninvasive monitoring; 3D } \\
\text { cell viability }\end{array}$ & $\begin{array}{l}\text { Real-time; noninvasive; } \\
\text { high throughput }\end{array}$ & [100] \\
\hline & A549 & EIS; in-air monitoring & $\begin{array}{l}\text { In situ and real-time } \\
\text { monitoring of } \\
\text { "air-exposed" cells }\end{array}$ & [101] \\
\hline Oxygen & $\begin{array}{l}\text { A549, HUVEC, } \\
\text { ASC, NHDF }\end{array}$ & $\begin{array}{c}\text { Oxygen-sensitive } \\
\text { microparticle-based biosensor } \\
\text { spot arrays }\end{array}$ & $\begin{array}{l}\text { Non-invasive, } \\
\text { real-time, label-free in } \\
\text { situ monitoring of } \\
\text { oxygen demands and } \\
\text { metabolic } \\
\text { activity }\end{array}$ & [102] \\
\hline Temperature & H1975 & $\begin{array}{l}\text { Pt thermosensor; cellular } \\
\text { temperature monitoring }\end{array}$ & $\begin{array}{c}\text { Non-disposable and } \\
\text { label-free }\end{array}$ & [103] \\
\hline
\end{tabular}

\section{Conclusions and Future Perspectives}

Biosensors are a new technology developed by combining biotechnology and electronic technology. They have the advantages of good selectivity, high sensitivity, fast analysis speed, and low cost, and can carry out continuous online monitoring in complex 
systems. Biosensors also have the advantages of high automation, miniaturization, and integration, which greatly reduce the requirements for the working environment. They are very suitable for field analysis, and have important application value in the fields of biology, medicine, environmental monitoring, food, medicine, and military medicine. The development of biosensors has generally gone through the following three stages: (1) the first generation of biosensors consists of electrochemical electrodes and inactive matrix membranes (dialysis membranes or reaction membranes) with fixed biological components; (2) the second generation of biosensors-biological components directly adsorbed or covalently bound to the surface of the converter-do not need the inactive matrix membrane, and do not need to add other reagents to the sample; (3) in the third generation of biosensors, biological components are directly fixed on the electronic components, and can directly sense and amplify the changes in interface substances, so as to combine biometric recognition and signal conversion processing. Biosensors have been incorporated into OOC platforms for a long time, in order to allow for in situ, real-time, small-volume detection of biochemical parameters with minor disturbances to the system [29,37,104-110]. In this review, we summarized biosensor-free (Table 1) and biosensor-integrated (Table 2) LOC models, illustrating the chip design and sensing signals of biosensor-integrated LOCs in detail by using examples of related studies. Biosensor research requires interdisciplinary knowledge of microfabrication, microengineering, materials science, chemistry, and biology. Major challenges for the successful integration of biosensors into OOC platforms are their miniaturization [111], biocompatibility, and flexibility. The trends in this field are as follows: (a) integrating more than one biosensor type, allowing for increased information acquisition and an increased feasibility of the model; and (b) increasing the detection ability of precise and personalized clinical testing devices. In summary, microfluidic-based biosensors play an important role in achieving high-throughput, highly sensitive, low-cost analysis. There is still a long way to go in the further development of integrated biosensors in LOCs, until more biosensors are explored and the advantages compared to off-chip assays are fully appreciated. Hopefully, this review will help both biologists and engineers to turn their minds to further development in the integration of biosensors in LOCs. The integration of microfluidic chips and biosensors has overcome the main difficulties in the initial stage of development, such as processing technology and flow control technology. The field is moving into a transformative period, where deeper basic research, extensive application, and in-depth industrialization should be accomplished. It is expected that in the near future, the sensor detection systems in microfluidic chips will replace complex equipment in traditional chemical analysis laboratories, and "personalized laboratories" that can monitor disease-related biochemical indicators will become a reality.

Author Contributions: Conceptualization, X.W. and H.Z.; writing-original draft preparation, S.D.; writing-review and editing, H.Z.; supervision, X.W. All authors have read and agreed to the published version of the manuscript.

Funding: This research was funded by the Fundamental Research Funds for the Central Universities and the Ordinary University Graduate Student Research Innovation Project of Jiangsu Province, China (KYCX18_0185), and the Science and Technology Grants of Jiangsu Province (BE2019716 and BE2019738).

Institutional Review Board Statement: Not applicable.

Informed Consent Statement: Not applicable.

Data Availability Statement: Not applicable.

Conflicts of Interest: The authors declare no conflict of interest.

\section{References}

1. Haefeli-Bleuer, B.; Weibel, E.R. Morphometry of the human pulmonary acinus. Anat. Rec. 1988, 220, 401-414. [CrossRef]

2. Mandell, L.A.; Niederman, M.S. Aspiration Pneumonia. N. Engl. J. Med. 2019, 380, 651-663. [CrossRef]

3. Lopez-Campos, J.L.; Tan, W.; Soriano, J.B. Global burden of COPD. Respirology 2016, 21, 14-23. [CrossRef] 
4. Singh, D.; Agusti, A.; Anzueto, A.; Barnes, P.J.; Bourbeau, J.; Celli, B.R.; Criner, G.J.; Frith, P.; Halpin, D.M.G.; Han, M.; et al. Global Strategy for the Diagnosis, Management, and Prevention of Chronic Obstructive Lung Disease: The GOLD science committee report 2019. Eur. Respir. J. 2019, 53, 1900164. [CrossRef]

5. Papi, A.; Brightling, C.; Pedersen, S.E.; Reddel, H.K. Asthma. Lancet 2018, 391, 783-800. [CrossRef]

6. Lemjabbar-Alaoui, H.; Hassan, O.U.; Yang, Y.W.; Buchanan, P. Lung cancer: Biology and treatment options. Biochim. Biophys. Acta (BBA) Bioenerg. 2015, 1856, 189-210. [CrossRef] [PubMed]

7. Barta, J.A.; Powell, C.A.; Wisnivesky, J.P. Global Epidemiology of Lung Cancer. Ann. Glob. Health 2019, 85. [CrossRef] [PubMed]

8. Siegel, R.L.; Miller, K.D.; Fuchs, H.E.; Jemal, A. Cancer Statistics, 2021. CA Cancer J. Clin. 2021, 71, 7-33. [CrossRef]

9. Harrison, D.J.; Manz, A.; Fan, Z.H.; Ludi, H.; Widmer, H.M. Capillary electrophoresis and sample injection systems integrated on a planar glass chip. Anal. Chem. 1992, 64, 1926-1932. [CrossRef]

10. Thorsen, T.; Maerkl, S.J.; Quake, S.R. Microfluidic large-scale integration. Science 2002, 298, 580-584. [CrossRef]

11. Bhatia, S.N.; Ingber, D.E. Microfluidic organs-on-chips. Nat. Biotechnol. 2014, 32, 760-772. [CrossRef]

12. Huh, D.; Matthews, B.D.; Mammoto, A.; Montoya-Zavala, M.; Hsin, H.Y.; Ingber, D.E. Reconstituting organ-level lung functions on a chip. Science 2010, 328, 1662-1668. [CrossRef]

13. Benam, K.H.; Novak, R.; Nawroth, J.; Hirano-Kobayashi, M.; Ferrante, T.C.; Choe, Y.; Prantil-Baun, R.; Weaver, J.C.; Bahinski, A.; Parker, K.K.; et al. Matched-Comparative Modeling of Normal and Diseased Human Airway Responses Using a Microengineered Breathing Lung Chip. Cell Syst. 2016, 3, 456-466.e4. [CrossRef]

14. Hassell, B.A.; Goyal, G.; Lee, E.; Sontheimer-Phelps, A.; Levy, O.; Chen, C.S.; Ingber, D.E. Human Organ Chip Models Recapitulate Orthotopic Lung Cancer Growth, Therapeutic Responses, and Tumor Dormancy In Vitro. Cell Rep. 2017, 21, 508-516. [CrossRef]

15. Khazali, A.S.; Clark, A.M.; Wells, A. A Pathway to Personalizing Therapy for Metastases Using Liver-on-a-Chip Platforms. Stem Cell Rev. Rep. 2017, 13, 364-380. [CrossRef]

16. Beckwitt, C.H.; Clark, A.M.; Wheeler, S.; Taylor, D.L.; Stolz, D.B.; Griffith, L.; Wells, A. Liver 'organ on a chip'. Exp. Cell Res. 2018, 363, 15-25. [CrossRef] [PubMed]

17. Lasli, S.; Kim, H.J.; Lee, K.; Suurmond, C.E.; Goudie, M.; Bandaru, P.; Sun, W.; Zhang, S.; Zhang, N.; Ahadian, S.; et al. A Human Liver-on-a-Chip Platform for Modeling Nonalcoholic Fatty Liver Disease. Adv. Biosyst. 2019, 3, e1900104. [CrossRef] [PubMed]

18. Ashammakhi, N.; Nasiri, R.; Barros, N.R.; Tebon, P.; Thakor, J.; Goudie, M.; Shamloo, A.; Martin, M.G.; Khademhosseini, A. Gut-on-a-chip: Current progress and future opportunities. Biomaterials 2020, 255, 120196. [CrossRef]

19. Poceviciute, R.; Ismagilov, R.F. Human-gut-microbiome on a chip. Nat. Biomed. Eng. 2019, 3, 500-501. [CrossRef] [PubMed]

20. Lee, J.; Kim, S. Kidney-on-a-Chip: A New Technology for Predicting Drug Efficacy, Interactions, and Drug-induced Nephrotoxicity. Curr. Drug Metab. 2018, 19, 577-583. [CrossRef] [PubMed]

21. Wilmer, M.J.; Ng, C.P.; Lanz, H.L.; Vulto, P.; Suter-Dick, L.; Masereeuw, R. Kidney-on-a-Chip Technology for Drug-Induced Nephrotoxicity Screening. Trends Biotechnol. 2016, 34, 156-170. [CrossRef] [PubMed]

22. Zhang, Y.S.; Arneri, A.; Bersini, S.; Shin, S.R.; Zhu, K.; Goli-Malekabadi, Z.; Aleman, J.; Colosi, C.; Busignani, F.; Dell'Erba, V.; et al. Bioprinting 3D microfibrous scaffolds for engineering endothelialized myocardium and heart-on-a-chip. Biomaterials 2016, 110, 45-59. [CrossRef]

23. Sakamiya, M.; Fang, Y.; Mo, X.; Shen, J.; Zhang, T. A heart-on-a-chip platform for online monitoring of contractile behavior via digital image processing and piezoelectric sensing technique. Med. Eng. Phys. 2020, 75, 36-44. [CrossRef]

24. Potkay, J.A. The promise of microfluidic artificial lungs. Lab Chip 2014, 14, 4122-4138. [CrossRef]

25. Alhadrami, H.A. Biosensors: Classifications, medical applications, and future prospective. Biotechnol. Appl. Biochem. 2018, 65, 497-508. [CrossRef] [PubMed]

26. Li, Y.-C.E.; Lee, I.C. The Current Trends of Biosensors in Tissue Engineering. Biosensors 2020, 10, 88. [CrossRef]

27. Alsabbagh, K.; Hornung, T.; Voigt, A.; Sadir, S.; Rajabi, T.; Lange, K. Microfluidic Impedance Biosensor Chips Using Sensing Layers Based on DNA-Based Self-Assembled Monolayers for Label-Free Detection of Proteins. Biosensors 2021, 11, 80. [CrossRef]

28. Chao, L.; Shi, H.; Nie, K.; Dong, B.; Ding, J.; Long, M.; Liu, Z. Applications of Field Effect Transistor Biosensors Integrated in Microfluidic Chips. Nanosci. Nanotechnol. Lett. 2020, 12, 427-445. [CrossRef]

29. Liao, Z.; Wang, J.; Zhang, P.; Zhang, Y.; Miao, Y.; Gao, S.; Deng, Y.; Geng, L. Recent advances in microfluidic chip integrated electronic biosensors for multiplexed detection. Biosens. Bioelectron. 2018, 121, 272-280. [CrossRef]

30. Sun, T.; Tsuda, S.; Zauner, K.P.; Morgan, H. On-chip electrical impedance tomography for imaging biological cells. Biosens. Bioelectron. 2010, 25, 1109-1115. [CrossRef]

31. Wang, J.; Wu, C.; Hu, N.; Zhou, J.; Du, L.; Wang, P. Microfabricated electrochemical cell-based biosensors for analysis of living cells in vitro. Biosensors 2012, 2, 127-170. [CrossRef]

32. Cui, F.; Zhou, Z.; Zhou, H.S. Review-Measurement and Analysis of Cancer Biomarkers Based on Electrochemical Biosensors. J. Electrochem. Soc. 2019, 167. [CrossRef]

33. Kaur, G.; Tomar, M.; Gupta, V. Development of a microfluidic electrochemical biosensor: Prospect for point-of-care cholesterol monitoring. Sens. Actuators B Chem. 2018, 261, 460-466. [CrossRef]

34. Kasturi, S.; Torati, S.R.; Eom, Y.; Kim, C. Microvalve-controlled miniaturized electrochemical lab-on-a-chip based biosensor for the detection of beta-amyloid biomarker. J. Ind. Eng. Chem. 2021, 97, 349-355. [CrossRef]

35. An, L.; Wang, G.; Han, Y.; Li, T.; Jin, P.; Liu, S. Electrochemical biosensor for cancer cell detection based on a surface 3D micro-array. Lab Chip 2018, 18, 335-342. [CrossRef] 
36. Pires, N.M.M.; Dong, T.; Hanke, U.; Hoivik, N. Recent Developments in Optical Detection Technologies in Lab-on-a-Chip Devices for Biosensing Applications. Sensors 2014, 14, 15458-15479. [CrossRef] [PubMed]

37. Liao, Z.; Zhang, Y.; Li, Y.; Miao, Y.; Gao, S.; Lin, F.; Deng, Y.; Geng, L. Microfluidic chip coupled with optical biosensors for simultaneous detection of multiple analytes: A review. Biosens. Bioelectron. 2019, 126, 697-706. [CrossRef]

38. Chen, Y.-T.; Lee, Y.-C.; Lai, Y.-H.; Lim, J.-C.; Huang, N.-T.; Lin, C.-T.; Huang, J.-J. Review of Integrated Optical Biosensors for Point-of-Care Applications. Biosensors 2020, 10, 209. [CrossRef]

39. Xing, Y.; Zhao, L.; Cheng, Z.; Lv, C.; Yu, F.; Yu, F. Microfluidics-Based Sensing of Biospecies. ACS Appl. Bio Mater. 2021, 4, 2160-2191. [CrossRef]

40. Fuchs, S.; Johansson, S.; Tjell, A.O.; Werr, G.; Mayr, T.; Tenje, M. In-Line Analysis of Organ-on-Chip Systems with Sensors: Integration, Fabrication, Challenges, and Potential. ACS Biomater. Sci. Eng. 2021, 7, 2926-2948. [CrossRef]

41. Benam, K.H.; Mazur, M.; Choe, Y.; Ferrante, T.C.; Novak, R.; Ingber, D.E. Human Lung Small Airway-on-a-Chip Protocol. Methods Mol. Biol. 2017, 1612, 345-365. [CrossRef] [PubMed]

42. Benam, K.H.; Villenave, R.; Lucchesi, C.; Varone, A.; Hubeau, C.; Lee, H.H.; Alves, S.E.; Salmon, M.; Ferrante, T.C.; Weaver, J.C.; et al. Small airway-on-a-chip enables analysis of human lung inflammation and drug responses in vitro. Nat. Methods 2016, 13, 151-157. [CrossRef]

43. Humayun, M.; Chow, C.-W.; Young, E.W.K. Microfluidic lung airway-on-a-chip with arrayable suspended gels for studying epithelial and smooth muscle cell interactions. Lab Chip 2018, 18, 1298-1309. [CrossRef] [PubMed]

44. Punde, T.H.; Wu, W.H.; Lien, P.C.; Chang, Y.L.; Kuo, P.H.; Chang, M.D.; Lee, K.Y.; Huang, C.D.; Kuo, H.P.; Chan, Y.F.; et al. A biologically inspired lung-on-a-chip device for the study of protein-induced lung inflammation. Integr. Biol. 2015, 7, 162-169. [CrossRef] [PubMed]

45. Nesmith, A.P.; Agarwal, A.; McCain, M.L.; Parker, K.K. Human airway musculature on a chip: An in vitro model of allergic asthmatic bronchoconstriction and bronchodilation. Lab Chip 2014, 14, 3925-3936. [CrossRef]

46. Huh, D.; Leslie, D.C.; Matthews, B.D.; Fraser, J.P.; Jurek, S.; Hamilton, G.A.; Thorneloe, K.S.; McAlexander, M.A.; Ingber, D.E. A human disease model of drug toxicity-induced pulmonary edema in a lung-on-a-chip microdevice. Sci. Transl. Med. 2012, 4, 159ra147. [CrossRef]

47. Zamprogno, P.; Wuthrich, S.; Achenbach, S.; Thoma, G.; Stucki, J.D.; Hobi, N.; Schneider-Daum, N.; Lehr, C.M.; Huwer, H.; Geiser, T.; et al. Second-generation lung-on-a-chip with an array of stretchable alveoli made with a biological membrane. Commun. Biol. 2021, 4, 1-10. [CrossRef]

48. Huang, D.; Liu, T.; Liao, J.; Maharjan, S.; Xie, X.; Perez, M.; Anaya, I.; Wang, S.; Tirado Mayer, A.; Kang, Z.; et al. Reversedengineered human alveolar lung-on-a-chip model. Proc. Natl. Acad. Sci. USA 2021, 118. [CrossRef]

49. Zhang, M.; Xu, C.; Jiang, L.; Qin, J. A 3D human lung-on-a-chip model for nanotoxicity testing. Toxicol. Res. 2018, 7, 1048-1060. [CrossRef]

50. Xu, C.; Zhang, M.; Chen, W.; Jiang, L.; Chen, C.; Qin, J. Assessment of Air Pollutant PM2.5 Pulmonary Exposure Using a 3D Lung-on-Chip Model. ACS Biomater. Sci. Eng. 2020, 6, 3081-3090. [CrossRef]

51. Xu, Z.; Li, E.; Guo, Z.; Yu, R.; Hao, H.; Xu, Y.; Sun, Z.; Li, X.; Lyu, J.; Wang, Q. Design and Construction of a Multi-Organ Microfluidic Chip Mimicking the in vivo Microenvironment of Lung Cancer Metastasis. ACS Appl. Mater. Interfaces 2016, 8 , 25840-25847. [CrossRef] [PubMed]

52. Srinivasan, B.; Kolli, A.R.; Esch, M.B.; Abaci, H.E.; Shuler, M.L.; Hickman, J.J. TEER measurement techniques for in vitro barrier model systems. J. Lab. Autom. 2015, 20, 107-126. [CrossRef]

53. Henry, O.Y.F.; Villenave, R.; Cronce, M.J.; Leineweber, W.D.; Benz, M.A.; Ingber, D.E. Organs-on-chips with integrated electrodes for trans-epithelial electrical resistance (TEER) measurements of human epithelial barrier function. Lab Chip 2017, 17, 2264-2271. [CrossRef]

54. Khalid, M.A.U.; Kim, Y.S.; Ali, M.; Lee, B.G.; Cho, Y.-J.; Choi, K.H. A lung cancer-on-chip platform with integrated biosensors for physiological monitoring and toxicity assessment. Biochem. Eng. J. 2020, 155, 107469. [CrossRef]

55. Mermoud, Y.; Felder, M.; Stucki, J.D.; Stucki, A.O.; Guenat, O.T. Microimpedance tomography system to monitor cell activity and membrane movements in a breathing lung-on-chip. Sens. Actuators B Chem. 2018, 255, 3647-3653. [CrossRef]

56. Stucki, A.O.; Stucki, J.D.; Hall, S.R.; Felder, M.; Mermoud, Y.; Schmid, R.A.; Geiser, T.; Guenat, O.T. A lung-on-a-chip array with an integrated bio-inspired respiration mechanism. Lab Chip 2015, 15, 1302-1310. [CrossRef]

57. Skardal, A.; Murphy, S.V.; Devarasetty, M.; Mead, I.; Kang, H.W.; Seol, Y.J.; Shrike Zhang, Y.; Shin, S.R.; Zhao, L.; Aleman, J.; et al. Multi-tissue interactions in an integrated three-tissue organ-on-a-chip platform. Sci. Rep. 2017, 7, 8837. [CrossRef]

58. Qiu, G.; Gai, Z.; Tao, Y.; Schmitt, J.; Kullak-Ublick, G.A.; Wang, J. Dual-Functional Plasmonic Photothermal Biosensors for Highly Accurate Severe Acute Respiratory Syndrome Coronavirus 2 Detection. ACS Nano 2020, 14, 5268-5277. [CrossRef] [PubMed]

59. Jin, C.E.; Lee, T.Y.; Koo, B.; Sung, H.; Kim, S.-H.; Shin, Y. Rapid virus diagnostic system using bio-optical sensor and microfluidic sample processing. Sens. Actuators B Chem. 2018, 255, 2399-2406. [CrossRef]

60. Fumet, J.-D.; Truntzer, C.; Yarchoan, M.; Ghiringhelli, F. Tumour mutational burden as a biomarker for immunotherapy: Current data and emerging concepts. Eur. J. Cancer 2020, 131, 40-50. [CrossRef]

61. Ballman, K.V. Biomarker: Predictive or Prognostic? J. Clin. Oncol. 2015, 33, 3968. [CrossRef] 
62. Schwaederle, M.; Zhao, M.; Lee, J.J.; Lazar, V.; Leyland-Jones, B.; Schilsky, R.L.; Mendelsohn, J.; Kurzrock, R. Association of Biomarker-Based Treatment Strategies With Response Rates and Progression-Free Survival in Refractory Malignant Neoplasms AMeta-analysis. JAMA Oncol. 2016, 2, 1452-1459. [CrossRef]

63. Jayanthi, V.S.P.K.S.A.; Das, A.B.; Saxena, U. Recent advances in biosensor development for the detection of cancer biomarkers. Biosens. Bioelectron. 2017, 91, 15-23. [CrossRef]

64. Califf, R.M. Biomarker definitions and their applications. Exp. Biol. Med. 2018, 243, 213-221. [CrossRef] [PubMed]

65. Wu, L.; Qu, X. Cancer biomarker detection: Recent achievements and challenges. Chem. Soc. Rev. 2015, 44, 2963-2997. [CrossRef] [PubMed]

66. Bock, C.; Halbritter, F.; Carmona, F.J.; Tierling, S.; Datlinger, P.; Assenov, Y.; Berdasco, M.; Bergmann, A.K.; Booher, K.; Busato, F.; et al. Quantitative comparison of DNA methylation assays for biomarker development and clinical applications. Nat. Biotechnol. 2016, 34, 726. [CrossRef]

67. Koch, A.; Joosten, S.C.; Feng, Z.; de Ruijter, T.C.; Draht, M.X.; Melotte, V.; Smits, K.M.; Veeck, J.; Herman, J.G.; Van Neste, L.; et al. Analysis of DNA methylation in cancer: Location revisited. Nat. Rev. Clin. Oncol. 2018, 15, 459-466. [CrossRef] [PubMed]

68. Thind, A.; Wilson, C. Exosomal miRNAs as cancer biomarkers and therapeutic targets. J. Extracell. Vesicles 2016, 5. [CrossRef]

69. Condrat, C.E.; Thompson, D.C.; Barbu, M.G.; Bugnar, O.L.; Boboc, A.; Cretoiu, D.; Suciu, N.; Cretoiu, S.M.; Voinea, S.C. miRNAs as Biomarkers in Disease: Latest Findings Regarding Their Role in Diagnosis and Prognosis. Cells 2020, 9, 276. [CrossRef]

70. Ghrera, A.S.; Pandey, C.M.; Malhotra, B.D. Multiwalled carbon nanotube modified microfluidic-based biosensor chip for nucleic acid detection. Sens. Actuators B Chem. 2018, 266, 329-336. [CrossRef]

71. Roether, J.; Chu, K.-Y.; Willenbacher, N.; Shen, A.Q.; Bhalla, N. Real-time monitoring of DNA immobilization and detection of DNA polymerase activity by a microfluidic nanoplasmonic platform. Biosens. Bioelectron. 2019, 142. [CrossRef]

72. Dutta, G.; Rainbow, J.; Zupancic, U.; Papamatthaiou, S.; Estrela, P.; Moschou, D. Microfluidic Devices for Label-Free DNA Detection. Chemosensors 2018, 6, 43. [CrossRef]

73. Lu, T.X.; Rothenberg, M.E. MicroRNA. J. Allergy Clin. Immunol. 2018, 141, 1202-1207. [CrossRef] [PubMed]

74. Cohen, J.D.; Javed, A.A.; Thoburn, C.; Wong, F.; Tie, J.; Gibbs, P.; Schmidt, C.M.; Yip-Schneider, M.T.; Allen, P.J.; Schattner, M.; et al. Combined circulating tumor DNA and protein biomarker-based liquid biopsy for the earlier detection of pancreatic cancers. Proc. Natl. Acad. Sci. USA 2017, 114, 10202-10207. [CrossRef] [PubMed]

75. Arbour, K.C.; Riely, G.J. Systemic Therapy for Locally Advanced and Metastatic Non-Small Cell Lung Cancer A Review. JAMA J. Am. Med. Assoc. 2019, 322, 764-774. [CrossRef] [PubMed]

76. Prelaj, A.; Tay, R.; Ferrara, R.; Chaput, N.; Besse, B.; Califano, R. Predictive biomarkers of response for immune checkpoint inhibitors in non-small-cell lung cancer. Eur. J. Cancer 2019, 106, 144-159. [CrossRef] [PubMed]

77. Sheng, Y.; Zhang, T.H.; Zhang, S.H.; Johnston, M.; Zheng, X.H.; Shan, Y.Y.; Liu, T.; Huang, Z.N.; Qian, F.Y.; Xie, Z.H.; et al. A CRISPR/Cas13a-powered catalytic electrochemical biosensor for successive and highly sensitive RNA diagnostics. Biosens. Bioelectron. 2021, 178, 10. [CrossRef]

78. Portela, A.; Calvo-Lozano, O.; Estevez, M.C.; Escuela, A.M.; Lechuga, L.M. Optical nanogap antennas as plasmonic biosensors for the detection of miRNA biomarkers. J. Mat. Chem. B 2020, 8, 4310-4317. [CrossRef]

79. Aoki, H.; Torimura, M.; Nakazato, T. 384-Channel electrochemical sensor array chips based on hybridization-triggered switching for simultaneous oligonucleotide detection. Biosens. Bioelectron. 2019, 136, 76-83. [CrossRef]

80. Zeng, N.; Xiang, J. Detection of KRAS G12D point mutation level by anchor-like DNA electrochemical biosensor. Talanta 2019, 198, 111-117. [CrossRef]

81. Wu, Y.; Kwak, K.J.; Agarwal, K.; Marras, A.; Wang, C.; Mao, Y.; Huang, X.; Ma, J.; Yu, B.; Lee, R.; et al. Detection of Extracellular RNAs in Cancer and Viral Infection via Tethered Cationic Lipoplex Nanoparticles Containing Molecular Beacons. Anal. Chem. 2013, 85, 11265-11274. [CrossRef] [PubMed]

82. Chiu, N.F.; Yang, H.T. High-Sensitivity Detection of the Lung Cancer Biomarker CYFRA21-1 in Serum Samples Using a CarboxylMoS2 Functional Film for SPR-Based Immunosensors. Front. Bioeng. Biotechnol. 2020, 8, 14. [CrossRef] [PubMed]

83. Cheng, S.; Hideshima, S.; Kuroiwa, S.; Nakanishi, T.; Osaka, T. Label-free detection of tumor markers using field effect transistor (FET)-based biosensors for lung cancer diagnosis. Sens. Actuators B Chem. 2015, 212, 329-334. [CrossRef]

84. Zou, Y.; Zhang, X.; An, C.; Ran, C.; Ying, K.; Wang, P. A point-of-care testing system with Love-wave sensor and immunogold staining enhancement for early detection of lung cancer. Biomed. Microdevices 2014, 16, 927-935. [CrossRef] [PubMed]

85. Chakravarty, S.; Lai, W.-C.; Zou, Y.; Drabkin, H.A.; Gemmill, R.M.; Simon, G.R.; Chin, S.H.; Chen, R.T. Multiplexed specific label-free detection of NCI-H358 lung cancer cell line lysates with silicon based photonic crystal microcavity biosensors. Biosens. Bioelectron. 2013, 43, 50-55. [CrossRef]

86. Feng, J.; Wu, T.; Cheng, Q.; Ma, H.; Ren, X.; Wang, X.; Lee, J.Y.; Wei, Q.; Ju, H. A microfluidic cathodic photoelectrochemical biosensor chip for the targeted detection of cytokeratin 19 fragments 21-1. Lab Chip 2021, 21, 378-384. [CrossRef] [PubMed]

87. Washburn, A.L.; Shia, W.W.; Lenkeit, K.A.; Lee, S.-H.; Bailey, R.C. Multiplexed cancer biomarker detection using chip-integrated silicon photonic sensor arrays. Analyst 2016, 141, 5358-5365. [CrossRef]

88. Gao, Y.; Huo, W.; Zhang, L.; Lian, J.; Tao, W.; Song, C.; Tang, J.; Shi, S.; Gao, Y. Multiplex measurement of twelve tumor markers using a GMR multi-biomarker immunoassay biosensor. Biosens. Bioelectron. 2019, 123, 204-210. [CrossRef]

89. Gao, A.; Yang, X.; Tong, J.; Zhou, L.; Wang, Y.; Zhao, J.; Mao, H.; Li, T. Multiplexed detection of lung cancer biomarkers in patients serum with CMOS-compatible silicon nanowire arrays. Biosens. Bioelectron. 2017, 91, 482-488. [CrossRef] 
90. Zhang, Y.; Liu, Y.; Liu, H.; Tang, W.H. Exosomes: Biogenesis, biologic function and clinical potential. Cell Biosci. $2019,9$. [CrossRef] [PubMed]

91. Tai, Y.-L.; Chen, K.-C.; Hsieh, J.-T.; Shen, T.-L. Exosomes in cancer development and clinical applications. Cancer Sci. 2018, 109, 2364-2374. [CrossRef]

92. Yu, W.; Hurley, J.; Roberts, D.; Chakrabortty, S.K.; Enderle, D.; Noerholm, M.; Breakefield, X.O.; Skog, J.K. Exosome-based liquid biopsies in cancer: Opportunities and challenges. Ann. Oncol. 2021, 32, 466-477. [CrossRef]

93. Yang, Q.; Cheng, L.; Hu, L.; Lou, D.; Zhang, T.; Li, J.; Zhu, Q.; Liu, F. An integrative microfluidic device for isolation and ultrasensitive detection of lung cancer-specific exosomes from patient urine. Biosens. Bioelectron. 2020, 163, 112290. [CrossRef]

94. Chen, H.; Zhang, Z.; Liu, H.; Zhang, Z.; Lin, C.; Wang, B. Hybrid magnetic and deformability based isolation of circulating tumor cells using microfluidics. AIP Adv. 2019, 9, 025023. [CrossRef]

95. Nguyen, N.V.; Jen, C.P. Impedance detection integrated with dielectrophoresis enrichment platform for lung circulating tumor cells in a microfluidic channel. Biosens. Bioelectron. 2018, 121, 10-18. [CrossRef]

96. Ngoc-Viet, N.; Yang, C.-H.; Liu, C.-J.; Kuo, C.-H.; Wu, D.-C.; Jen, C.-P. An Aptamer-Based Capacitive Sensing Platform for Specific Detection of Lung Carcinoma Cells in the Microfluidic Chip. Biosensors 2018, 8, 98. [CrossRef]

97. Nabovati, G.; Ghafar-Zadeh, E.; Letourneau, A.; Sawan, M. Towards High Throughput Cell Growth Screening: A New CMOS 8 $\times 8$ Biosensor Array for Life Science Applications. IEEE Trans. Biomed. Circuits Syst. 2017, 11, 380-391. [CrossRef] [PubMed]

98. Do, L.Q.; Thuy, H.T.T.; Bui, T.T.; Dau, V.T.; Nguyen, N.V.; Duc, T.C.; Jen, C.P. Dielectrophoresis Microfluidic Enrichment Platform with Built-In Capacitive Sensor for Rare Tumor Cell Detection. BioChip J. 2018, 12, 114-122. [CrossRef]

99. Li, Y.; Xu, T.; Zou, H.; Chen, X.; Sun, D.; Yang, M. Cell migration microfluidics for electrotaxis-based heterogeneity study of lung cancer cells. Biosens. Bioelectron. 2017, 89, 837-845. [CrossRef] [PubMed]

100. Pan, Y.; Jiang, D.; Gu, C.; Qiu, Y.; Wan, H.; Wang, P. 3D microgroove electrical impedance sensing to examine 3D cell cultures for antineoplastic drug assessment. Microsyst. Nanoeng. 2020, 6, 1-10. [CrossRef]

101. Noh, S.; Kim, H. In-air EIS sensor for in situ and real-time monitoring of in vitro epithelial cells under air-exposure. Lab Chip 2020, 20, 1751-1761. [CrossRef]

102. Zirath, H.; Rothbauer, M.; Spitz, S.; Bachmann, B.; Jordan, C.; Muller, B.; Ehgartner, J.; Priglinger, E.; Muhleder, S.; Redl, H.; et al. Every Breath You Take: Non-invasive Real-Time Oxygen Biosensing in Two- and Three-Dimensional Microfluidic Cell Models. Front. Physiol. 2018, 9, 815. [CrossRef]

103. Zhao, X.; Gao, W.; Yin, J.; Fan, W.; Wang, Z.; Hu, K.; Mai, Y.; Luan, A.; Xu, B.; Jin, Q. A high-precision thermometry microfluidic chip for real-time monitoring of the physiological process of live tumour cells. Talanta 2021, 226, 122101. [CrossRef]

104. Lafleur, J.P.; Joensson, A.; Senkbeil, S.; Kutter, J.P. Recent advances in lab-on-a-chip for biosensing applications. Biosens. Bioelectron. 2016, 76, 213-233. [CrossRef]

105. Luka, G.; Ahmadi, A.; Najjaran, H.; Alocilja, E.; DeRosa, M.; Wolthers, K.; Malki, A.; Aziz, H.; Althani, A.; Hoorfar, M. Microfluidics Integrated Biosensors: A Leading Technology towards Lab-on-a-Chip and Sensing Applications. Sensors 2015, 15, 30011-30031. [CrossRef]

106. Kumar, S.; Kumar, S.; Ali, M.A.; Anand, P.; Agrawal, V.V.; John, R.; Maji, S.; Malhotra, B.D. Microfluidic-integrated biosensors: Prospects for point-of-care diagnostics. Biotechnol. J. 2013, 8, 1267-1279. [CrossRef] [PubMed]

107. Loo, J.F.C.; Ho, A.H.P.; Turner, A.P.F.; Mak, W.C. Integrated Printed Microfluidic Biosensors. Trends Biotechnol. 2019, 37, 1104-1120. [CrossRef]

108. Khan, N.I.; Song, E. Lab-on-a-Chip Systems for Aptamer-Based Biosensing. Micromachines 2020, 11. [CrossRef]

109. Liu, Y.; Zhang, X. Microfluidics-Based Plasmonic Biosensing System Based on Patterned Plasmonic Nanostructure Arrays. Micromachines 2021, 12, 826. [CrossRef] [PubMed]

110. Liu, D.; Wang, J.; Wu, L.; Huang, Y.; Zhang, Y.; Zhu, M.; Wang, Y.; Zhu, Z.; Yang, C. Trends in miniaturized biosensors for point-of-care testing. TrAC-Trends Anal. Chem. 2020, 122. [CrossRef]

111. Derkus, B. Applying the miniaturization technologies for biosensor design. Biosens. Bioelectron. 2016, 79, 901-913. [CrossRef] [PubMed] 